\title{
PREDICTORS OF TREATMENT NON-ADHERENCE IN AN INPATIENT SUBSTANCE ABUSE REHABILITATION PROGRAMME
}

\author{
Johann TR Beuster \\ D Litt et Phil \\ Principal Lecturer, Department of Psychology, University of Johannesburg \\ Corresponding author: johannbeuster@hotmail.com
}

\author{
Robert Arnott \\ MA (Clinical Psychology) \\ Clinical Psychologist
}

Keywords: treatment adherence; treatment non-adherence; drop-out; substance rehabilitation programmes; substance abuse

\author{
Abbreviations: \\ DBT: $\quad$ Dialectical Behavioural Therapy \\ DSM-IV-TR: Diagnostic and Statistical Manual of Mental Disorders; $4^{\text {th }}$ edition (text revision) \\ SCID: $\quad$ Structured Clinical interview for the DSM-IV-TR \\ SHARP: $\quad$ Self-help Addiction Recovery Programme
}

\begin{abstract}
The research study aimed to identify the factors contributing to premature termination of treatment for substance addiction. The investigation took the form of a differential research design based on archival data obtained from patient files at an inpatient drug rehabilitation centre in Gauteng. One independent variable (treatment adherence) and five dependent variables (past and present patterns of scheduled medication use, legal history and DSM-IV-TR Axis I and II co-morbidity) were chosen. Eighty-five patient files were drawn, constituting 41 treatment adherent and 44 treatment non-adherent addicts. Extraneous variables of age, age of onset, duration of addiction, previous treatment history, drug of choice, current physical health status, gender, race, and level of education were equivalent in both samples. Univariate analysis indicated that treatment adherent and drop-out groups differed significantly in terms of legal history (Fisher's exact test $=12.369 ; p=0.002$ ) and past patterns of use of scheduled medication (Fisher's exact test $=29.131 ; p=0.000$ ). A logistic regression indicated that a history of abusing a combination of scheduled psychiatric and other medication prior to treatment is the single most accurate predictor of treatment non-adherence (Wald statistic $=11.1035, p=0.0009$ ). Although certain combinations of past medication patterns and legal history increase predicted probabilities of treatment non-adherence, legal history on its own failed to explain any further variance that past medication could not explain on its own.
\end{abstract}

\section{OPSOMMING}

Die doel van die navorsingsprojek was om faktore wat bydra tot premature staking van dwelmrehabilitasie te identifiseer. Die ondersoek het die vorm van 'n differensiële navorsingsontwerp met argivale data as basis aangeneem wat by ' $n$ binnepasiëntdwelmrehabilitasiesentrum in Gauteng verkry is. Een onafhanklike veranderlike (behandelingsnakoming) en vyf afhanklike veranderlikes (eertydse en huidige tendense van geskeduleerde medikasieverbruik, geregtelike verlede en DSM-IV-TR Aksis I en II komorbiditeit) is gekies vir die doel van die studie. Daar is 85 pasiëntlêers geselekteer wat bestaan het uit 41 behandelingvoltooiers en 44 behandelingstakers. Eksterne verandelikes van ouderdom, ouderdom van aanvang, duur van verslawing, vorige behandelingsgeskiedenis, dwelm van keuse, huidige fisiese gesondheidstatus, geslag, ras en vlak van onderwys was ekwivalent in beide steekproewe. Eenveranderlike 
analise het aangedui dat behandelingvoltooiers en stakers beduidend verskil het betreffende geregtelike verlede (Fisher se eksakte toets $=12.369 ; p=0.002$ ) en tendense van geskeduleerde medikasieverbruik voor opname (Fisher se eksakte toets $=29.131 ; p=0.000$ ). ' $n$ Logistiese regressie het aangedui dat ' $n$ geskiedenis van misbruik van 'n mengsel van psigiatriese en ander medikasie die enkel mees presiese voorspeller van behandelingstaking was (Wald statistiek $=11.1035, p=0.0009$ ). Hoewel sekere kombinasies van voormalige medikasie gebruikspatrone en geregtelike verlede die voorspelde waarskynlikheid van behandelingstaking vermeerder het, kon geregtelike verlede op op sigself geen verdere variansie verklaar, wat nie reeds deur medikasiegebruikspartone verklaar is nie.

\section{INTRODUCTION}

In August 2007 doctor Zola Skweyiya, the Social Development Minister, stated that substance abuse in South Africa is reaching crisis proportions as the following statistics reveal: At least seven percent of the inhabitants are alcohol dependent, whereas 31 percent are at risk of developing serious drinking problems. More than 800000 South Africans use 123 metric tons of cannabis per year, whereas 265000 consume five metric tons of cocaine per annum. An estimated 1.2 million citizens furthermore abuse amphetamines (Hosken, 2007:1). These alarming statistics emphasise not only the need for effective rehabilitation programmes, but also the necessity that addicts successfully complete treatment. Premature treatment termination is, however, a major problem at drug addiction treatment centres and has serious prognostic and financial implications (King \& Canada, 2004:189). Gillmore, Lash, Foster and Blosser (2001:524) found that on average $50 \%$ of patients drop out of rehabilitation programmes within the first five weeks of admission. Addicts who drop out have a poorer prognosis than those who complete treatment programmes. In this regard Gillmore et al. (2001:525) state that treatment drop-outs have the same treatment outcomes as untreated addicts. The same authors furthermore found that interventions aimed at improving adherence to rehabilitation programmes reduced readmission by $66 \%$ over a six-month period (Gillmore et al. 2001:537). Identifying factors contributing to treatment non-adherence can therefore guide the clinician to design special interventions to prevent patient attrition. In this regard the article intends to give an overview of factors leading to treatment drop-out and then to explore the role of five possible factors contributing to this problem. To add to the existing body of knowledge, the authors investigated patterns of supplementary psychiatric and general scheduled medication use, legal history, and DSM-IV-TR Axis I and II co-morbidity as predictors of non-adherence in rehabilitation programmes. This study was conducted at the SHARP inpatient treatment centre in Johannesburg. This rehabilitation centre deals with a wide range of substance addiction including, alcohol, amphetamines, hallucinogens, opioids, cannabis, inhalants and polysubstances. The SHARP centre employs the Minnesota rehabilitation model which includes the 12-step principles of Alcoholics Anonymous (AA) and Narcotics Anonymous (NA).

\section{PREDICTORS OF PREMATURE TREAT- MENT DROP-OUT}

\section{Demographic predictors}

\section{Age}

Research indicates that the role of age in treatment drop-out is unclear. Brown, O'Grady, Farrell, Flechner and Nurco (2001:147) found that age does not significantly distinguish treatment adherent from treatment non-adherent groups. Slesnick (2001:411-2), however, found that adolescent addicts tend to drop out of treatment programmes at an early stage. The attrition rate is so high that only $10-18 \%$ of youths complete rehabilitation programmes. She also found that such patients are less motivated to change and are difficult to engage in therapy. Similar findings were obtained by Agosti, Nunes and Ocepeck-Welikson (1996:29), showing that drop-outs among cocaine addicts tend to be younger and have an earlier onset of substance abuse.

\section{Gender}

Some studies show that women have poorer treatment retention, whereas other researchers fail to find a gender difference in adherence (King et al. 2004:190). Many samples, however, contain more men than women, and men are more often coerced into treatment, which might account for compliance rates being biased towards males. Haller, Miles and Dawson (2002:431) further report that lack of resources such as inadequate childcare contribute to the fact that women prematurely terminate addiction treatment. 


\section{Combination of age and gender}

Sannibale, Hurkett, Van den Bossche, O'Connor, Zador, Capus, Gregory and McKenzie (2003:187) found that older female patients are more likely to adhere to aftercare programmes than younger male patients. Similarly Copeland and Hall (1992:888) found that women under the age of 25 are more likely to drop out of rehabilitation programmes.

\section{Ethnicity}

Once again mixed results are found in the literature. Some studies indicate that ethnic minorities (for example, African and Hispanic Americans) tend to drop out of rehabilitation sooner than their Caucasian counterparts (Wickizer, Maynard, Atherly, Frederick, Koepsell, Krupski \& Stark, 1994:216; Agosti et al. 1996:29). Other surveys, however, contradict this finding (King et al. 2004:190).

It would seem that racial bias could play a part in early drop-out of ethnic minorities. In this regard Wickizer et al. (1994:216) state: "Ethnicity per se might not be as important as the fit between one's ethnic group and the norms and culture of the programme."

\section{Education}

Findings about treatment compliance are fairly consistent, indicating that better educated patients tend to complete treatment more readily (Wickizer et al. 1994:219). Low levels of education would then relate to treatment non-engagement (King et al. 2004:189).

\section{Socio-economic status}

Unemployment predicts poor treatment adherence (Claus \& Kindleberger, 2002:25; King et al. 2004:189). Similar findings were reported by Copeland and Hall (1992:889) who state that "unemployment is the strongest predictor of treatment drop-out in women". Similar findings show that lower-income groups tend to be less likely to complete drug rehabilitation programmes (Vendetti, McRee, Miller, Christiansen \& Herrell, 2002:126).

\section{Health status}

Patients with serious health problems related to drinking, for example, cirrhosis of the liver, tend to be more treatment compliant (Wickizer et al. 1994:216). In this regard it seems that severe impairment in health might serve as a motivating factor in treatment adherence.

\section{Patterns of prescription medication use}

No mention was found in the literature concerning the relationship between past and present patterns of prescription medication use and pre-mature drop-out. In this regard this study makes a new contribution to the field by hypothesising that an addict's history of using psychiatric and other scheduled medication might have an influence on treatment compliance.

\section{Relationship status and social support}

This contributing factor yet again yields mixed results. A large body of research indicates that social support, or the lack of it, does influence treatment adherence. Lack of significant social support predicts poor treatment retention, whereas the presence of a supportive social environment prevents premature drop-out (Kelly \& Moos, 2003:241; King et al. 2004:190). Researchers furthermore indicate that being single relates to treatment attrition, whereas being married with dependants at home relates to treatment completion (Wickizer et al. 1994:216; Kelly et al. 2003:244). The importance of social support was, however, contradicted by the findings of Brown et al. (2001:148) who failed to find a relationship between quality of relationships and treatment adherence.

\section{Religiosity}

Religious conviction also shows contradictory results. Brown et al. (2001:148), for example, failed to find a link between religiosity and treatment adherence, whereas Kelly et al. (2003:344) report that strong religious beliefs relate to treatment adherence.

\section{Legal history}

A history of multiple drug-related arrests is associated with treatment drop-out (King et al. 2004:190). Claus et al. (2002:25) similarly found that prisoners on probation are more likely to prematurely terminate rehabilitation treatment. This finding was challenged by Brown et al. (2001:156) who found that patients with long histories of criminal activity and a higher incidence of arrests are more likely to be adherent in out-patient 12 step programmes.

\section{Patterns and intensity of substance abuse}

In terms of substance of choice, no clear predictors of treatment adherence emerge. There are indications that addiction to cocaine, a long history of substance abuse 
and a greater number of previous treatments relate to non-adherence (King et al. 2004:190). Agosti et al. (1996:29) obtained similar findings, showing that intravenous or freebase cocaine users tend to have a high drop-out rate.

The number of years of heroin abuse also has a negative effect on treatment completion for first-time rehabilitation patients (Ravndal, Vaglum \& Lauritzen, 2005:180). Copeland et al. (1992:889) reported similar findings by stating that women who nominate heroin as drug of choice tend to drop out of rehabilitation programmes.

Poly-substance abusers have lower adherence to after-care treatment and also have the poorest prognosis (Sannibale et al. 2003:188). Brown et al. (2001:154), nevertheless, found that patients with a long history of serious drug abuse more regularly attend 12-step treatment programmes. This study also showed that serious long-term abusers of cocaine, heroin and other opiates tend to adhere better to treatment.

\section{Treatment modality}

Findings consistently show that the drop-out rate is higher in outpatient programmes than in in-house treatment programmes (Claus et al. 2002:26).

\section{Motivation, attitudes and expectations}

Mixed results are obtained from psychometric tests concerning the link between motivation, attitudes and expectations towards treatment and treatment adherence (Gillmore et al. 2001:525). Claus et al. (2002:30) claim that internal motivation to change does not have a significant effect on treatment adherence, whereas Gillmore et al. (2001: 524) found that candid acknowledgement of addiction is not an accurate predictor of treatment adherence.

\section{Measures on the Negative Treatment In- dicator Scale of the MMPI-2}

Addicts who score high on the Negative Treatment Indicator Scale of the MMPI-2 not only tend to drop out of rehabilitation programmes, but they also have a tendency not to return to treatment. High scorers on this scale have negative attitudes towards mental health programmes and health care professionals in general.
They are reluctant to discuss their problems openly and do not believe that they can be helped or understood. High scorers are apathetic, have a tendency to give up before trying, and do not believe that rehabilitation is possible. They are consequently not motivated to change their lives (Gillmore et al. 2001:524-8).

\section{Co-morbidity with other psychopathology}

Co-morbidity with other forms of DSM-IV-TR pathology is once again not a clear predictor of pre-mature treatment drop-out. Brown et al. (2001:154), for example, did not find significant differences in co-morbid psychopathology between treatment adherent and treatment non-adherent groups.

\section{Axis I}

Other studies nevertheless indicate that patients with anxiety-based disorder co-morbidity tend to adhere better to treatment programmes (Gillmore et al. 2001:526). In the same way Claus et al. (2002:25-6) report that patients suffering from anxiety concurrent with depression are more likely to complete rehabilitation programmes. Depression with somatisation, on the other hand, is associated with premature termination (Haller et al. 2002:431).

The findings concerning depression without anxiety are not consistent. Depression accompanied by a tendency to avoid responsibility, for instance, seems to lead to treatment non-adherence (King et al. 2004:190). Haller et al. (2002:435) furthermore confirm that major depression is associated with premature drop-out. These findings were, however, contradicted by Brown et al. (2001:154) and Agosti et al. (1996:29), who failed to find a link between treatment attrition and depression.

Hypomania predictably relates to premature drop-out (Gillmore et al. 2001:525), whereas addicts in the psychotic range also tend to have higher treatment attrition (Haller et al. 2002:435).

\section{Personality disorders}

From the literature it is evident that the co-morbidity of substance abuse and personality disorders is very high . In this regard Ball, Cobb-Richardson, Connolly, Bujosa and O'Neall (2005:371) state: "Across studies involving different samples, settings and methods of assessment, more than half of treated substance abusers have 
at least one personality disorder, and the majority has more than one such disorder." In this regard Ball et al. (2005:375) state that borderline- and anti-social personality disorders often co-occur with substance abuse. Establishing the relationship of Axis II co-morbidity with treatment compliance, however, seems to be a complex matter.

Once again the literature reports mixed results, as some authors found that the presence of anti-social, borderline and histrionic personality traits contribute to nonadherence in rehabilitation programmes (Gillmore et al.2001:525). Others, conversely, failed to confirm this hypothesis (Ravndal et al. 2005:183). Haller et al. (2002:431), nevertheless argue that women suffering from Cluster B disorders are able to complete rehabilitation if a sufficient "holding environment is maintained".

\section{Other psychological factors}

\section{Sexual abuse}

Claus et al. (2002:25) found that patients reporting sexual and physical abuse in childhood are more likely to drop out of treatment. Apparently childhood abuse has a negative effect on the development of social skills, which in turn reduces the patient's ability to co-operate in treatment programmes. Interestingly, however, Copeland et al. (1992:888) found that women who suffered from sexual assault in adulthood tended to be treatment adherent.

\section{EVALUATION OF THE LITERATURE}

Perusing the literature, it becomes evident that most of the findings attempting to predict premature drop-out are contradictory. Disparate results are probably due to "differences in subject populations, methods and measures, and definitions of treatment completion" (Wickizer et al. 1994:215). Many studies are also based on one treatment episode only (Wickizer et al. 1994:220).

\section{PRACTICAL IMPLICATIONS OF THE LIT- ERATURE}

Identifying special risk factors of treatment drop-out, allows clinicians to "place such clients in appropriate or targeted programmes" (King et al. 2004:190) to prevent treatment non-adherence.

\section{RESEARCH METHODS}

\section{Problem statement and research design}

The current study endeavoured not only to verify some past research findings, but also introduced new variables that could have an influence on premature treatment drop-out. Many of the demographic variables mentioned in the literature section were kept constant by selecting equivalent adherent and non-adherent samples.

A differential research design based on archival data (obtained from the SHARP inpatient treatment centre) was employed to establish patient-related predictors of treatment adherence. A differential research design involves two or more pre-existing groups and the independent variable is not manipulated. In this regard the independent variable of treatment adherence involved the selection of two separate pre-existing groups. These were treatment adherent and treatment non-adherent patients.

The researchers furthermore investigated whether five dependent variables predict treatment compliance or premature treatment attrition. These included: Axis I and II psychopathology, legal history and patterns of prescription medication use. In the following section the dependent and independent variables will be described.

\section{Variables}

\section{Independent variable}

The independent variable category treatment adherent indicates that patients completed the full drug rehabilitation programme, which implies that they completed 13 weeks of the 12-step in-patient treatment programme at the SHARP centre.

The independent variable category treatment non-adherent indicates that patients did not complete the full drug rehabilitation programme, but dropped out within the first seven weeks.

\section{Dependent variables}

Five dependent variables were employed in the study. Each of these variables had two or more distinct categories. A brief description of these will be given in the 
following section.

\section{Dependent variable A: Legal history}

Legal history refers to the participant's criminal record. Three categories were assigned in this case:

- no criminal record (the patient had never been arrested or convicted for a criminal activity);

- criminal record (the patient had been arrested and had been found guilty of the crime); and

- arrested, but no criminal record (the patient had been arrested, but had not been found guilty of the felony).

\section{Dependent variable B: Supplementary scheduled} medication current

This variable refers to scheduled medication taken by the patient during the treatment programme, as prescribed by a medical doctor or psychiatrist. Only three categories were found in the sample:

- psychiatric drugs;

- psychiatric drugs and general prescription medication for valid medical or psychiatric conditions; and

- none.

\section{Dependent variable C: Supplementary scheduled medication on admission}

This variable refers to additional prescription medication used by the patient on admission to the rehabilitation programme. This category excludes the patient's drug-of-choice (substance addiction). Only three categories were found in the sample:

- psychiatric drugs;

- $\quad$ psychiatric drugs and general scheduled medication for medical or psychiatric conditions; and

- none.

Dependent variable D: Co-morbidity Axis I This variable refers to the patient's DSM-IV-TR Axis I co-morbidity. Only five types of co-morbid Axis I pathology were found in the sample. Six categories were therefore assigned:

- Anxiety-based disorders (this category included anxiety, somatoform and dissociative disorders);

- Mood disorders (this category included both unipolar and bipolar mood disturbances);

- Psychosis;
- Eating disorders (including anorexia nervosa and bulimia);

- Adult attention deficit disorder; and

- None (no Axis I co-morbidity).

Dependent variable E: Co-morbidity Axis II - Cluster $B$

This variable refers to the presence of co-morbid DSMIV-TR personality disorders. Only two Cluster B categories were found in the sample and included borderline and anti-social personality disorders. The following categories were therefore assigned:

- borderline personality disorder;

- anti-social personality disorder; and

- none (no Axis II co-morbidity).

\section{Numeric characteristics of data}

All dependent variables concern nominal information and represent frequencies of non-numerical categories.

\section{Description of sample}

An availability sample of 85 patients was drawn from inclusive SHARP patient files dating from the period 2001 to 2005. Of these 41 were treatment adherent and 44 were treatment non-adherent. Possible extraneous variables of age, age of onset, duration of addiction, previous treatment history, addict's drug-of-choice, current physical health status, gender, race, and level of education were controlled. Table 1 summarises these characteristics of the participants.

Table 1 indicates that the average age of the sample was 29.26 years $(30.42=$ adherent; $28.11=$ non-adherent). The average age of onset of substance use was 15.98 years for the adherent group and 15.66 for the non-adherent group. The mean duration of substance abuse was 14.2 years for the adherent group and 12.23 for the non-adherent group. The greater part of the sample had received previous treatment for substance addiction ( $40=$ adherent and $43=$ non-adherent). The treatment adherent group consisted of 26 males and 15 females, whereas the non-adherent group comprised of 29 males and 15 females. The majority of the overall sample was therefore male. The overall sample contained a majority of white South Africans (36 = adherent and $40=$ non-adherent). Other racial groups were poorly represented. The majority of patients were physi- 
Table 1: Sample characteristics

\begin{tabular}{|c|c|c|c|c|}
\hline \multicolumn{5}{|c|}{ Sample characteristics } \\
\hline & $\begin{array}{l}\text { Treatment } \\
\text { adherent group } \\
\mathrm{N}=41\end{array}$ & $\begin{array}{l}\text { Treatment } \\
\text { non-adherent } \\
\text { group } N=44\end{array}$ & Test statistic & $\begin{array}{l}\text { 2-sided } \\
\text { significance }\end{array}$ \\
\hline $\begin{array}{l}\text { Average age }= \\
29.26\end{array}$ & $\begin{array}{l}\text { Mean age }=30.42 \\
s d=8.93\end{array}$ & $\begin{array}{l}\text { Mean age }=28.11 \\
s d=7.67\end{array}$ & $t=1.278$ & $0.205^{\mathrm{a}}$ \\
\hline $\begin{array}{l}\text { Age of onset of } \\
\text { abuse }\end{array}$ & $\begin{array}{l}\text { Mean age }=15.98 \\
s d=4.65\end{array}$ & $\begin{array}{l}\text { Mean age }=15.66 \\
s d=3.18\end{array}$ & $t=0.368$ & $0.714^{\mathrm{a}}$ \\
\hline $\begin{array}{l}\text { Duration } \\
\text { of addiction }\end{array}$ & $\begin{array}{l}\text { Mean duration } \\
=14.2, \mathrm{sd}=8.14\end{array}$ & $\begin{array}{l}\text { Mean duration } \\
=12.23, \mathrm{sd}=7.45\end{array}$ & $t=1.164$ & $0.248^{\mathrm{a}}$ \\
\hline \multirow[t]{2}{*}{ Treatment history } & $\begin{array}{l}40 \text { previous } \\
\text { treatment }\end{array}$ & $\begin{array}{l}43 \text { previous } \\
\text { treatment }\end{array}$ & \multirow[t]{2}{*}{$X^{2}=0.003$} & \multirow[t]{2}{*}{$1.00^{a}$} \\
\hline & $\begin{array}{l}1 \text { no previous } \\
\text { treatment }\end{array}$ & $\begin{array}{l}1 \text { no previous } \\
\text { treatment }\end{array}$ & & \\
\hline \multirow[t]{2}{*}{ Gender } & 26 male & 29 male & \multirow[t]{2}{*}{$X^{2}=0.058$} & \multirow[t]{2}{*}{$0.824^{\mathrm{a}}$} \\
\hline & 15 female & 15 female & & \\
\hline \multirow[t]{4}{*}{ Racial group } & 36 Caucasian & 40 Caucasian & \multirow[t]{4}{*}{$\begin{array}{l}\text { Fisher's exact } \\
\text { test }=1.695\end{array}$} & \multirow[t]{4}{*}{$0.75^{a}$} \\
\hline & 1 African & 2 African & & \\
\hline & 1 Asian & 1 Asian & & \\
\hline & 3 Coloured & 1 Coloured & & \\
\hline \multirow{2}{*}{$\begin{array}{l}\text { Physical health } \\
\text { status on } \\
\text { admission }\end{array}$} & $\begin{array}{l}36 \text { good physical } \\
\text { health }\end{array}$ & $\begin{array}{l}41 \text { good physical } \\
\text { health }\end{array}$ & \multirow[t]{2}{*}{$x^{2}=0.72$} & \multirow[t]{2}{*}{$0.474^{\mathrm{a}}$} \\
\hline & 5 chronic disease & 3 chronic disease & & \\
\hline \multirow[t]{5}{*}{ Level of education } & 0 No schooling & 0 No schooling & \multirow{5}{*}{$\begin{array}{l}\text { Fisher's exact } \\
=1.04\end{array}$} & \multirow[t]{5}{*}{$0.8^{\mathrm{a}}$} \\
\hline & $\begin{array}{l}9 \text { Primary school } \\
\text { Grades } 1-7\end{array}$ & $\begin{array}{l}13 \text { Primary school } \\
\text { Grades } 1-7\end{array}$ & & \\
\hline & $\begin{array}{l}18 \text { Secondary } \\
\text { school } \\
\text { Grades 8-12 }\end{array}$ & $\begin{array}{l}\text { 19 Secondary } \\
\text { school } \\
\text { Grades 8-12 }\end{array}$ & & \\
\hline & $\begin{array}{l}7 \text { College or } \\
\text { Technikon diploma }\end{array}$ & $\begin{array}{l}5 \text { College or } \\
\text { Technikon diploma }\end{array}$ & & \\
\hline & 7 University degree & 7 University degree & & \\
\hline \multirow{6}{*}{$\begin{array}{l}\text { Substance of } \\
\text { choice }\end{array}$} & 8 Alcohol & 5 Alcohol & \multirow{6}{*}{$\begin{array}{l}\text { Fisher's exact } \\
=4.072\end{array}$} & \multirow[t]{6}{*}{$0.582^{\mathrm{a}}$} \\
\hline & 19 Amphetamines & 16 Amphetamines & & \\
\hline & 1 Hallucinogens & 2 Hallucinogens & & \\
\hline & 9 Opioids & 11 Opioids & & \\
\hline & $\begin{array}{l}1 \text { Other - Cannabis } \\
\text { and inhalants }\end{array}$ & $\begin{array}{l}2 \text { Other - Cannabis } \\
\text { and inhalants }\end{array}$ & & \\
\hline & 3 Poly-substances & 8 Poly-substances & & \\
\hline
\end{tabular}


cally healthy on admission to the treatment programme (36 = adherent and 41 = non-adherent). Level of education and substance of choice were not statistically different in the two groups and neither was there a difference in terms of substance of choice. Table 1 therefore indicates that no statistical difference was found between the sample characteristics of the two sample groups. The sample groups were therefore considered to be equivalent in terms of these extraneous variables.

\section{Data collection}

All information was obtained from patient files at the SHARP Treatment Centre. An inclusive file consisted of a bio-psychosocial interview, the Structured Clinical Interview for the DSM-IV-TR (SCID), medication charts as well as medical prescriptions (where applicable), counselling progress notes and psychiatric reports. The bio-psychosocial interview is a structured questionnaire constructed by the SHARP centre and was conducted within 48 hours of admission by the client's focal counsellor. Information obtained in this interview was verified by means of collateral information from family members, spouses or partners. Progress notes were subsequently made by the focal counsellor over the duration of treatment. Each patient was also assessed by a psychiatrist and a medical practitioner. The bio-psychosocial interview, medical charts, prescriptions and process notes gave information concerning sample characteristics (mentioned in Table 1) and dependent variables A, B and C. The SCID was conducted by one of three psychiatrists and yielded information concerning Axis I and II co-morbidity. Health-related problems were attended to by one of two consultant medical doctors.

\section{Reliability and validity of the SCID}

The SCID is a structured clinical interview assessing psychopathology based on clear DSM-IV-TR criteria. Responses to questions are rated in three possible ways where a score of 1 indicates the absence of a symptom, 2 refers to its presence, but below the required threshold, and 3 denotes its full presence (Nelson-Gray, Huprich, Kissling \& Ketchum, 2004:221).

Miller, Dasher, Collins, Griffiths and Brown (2001:255) report that the SCID has excellent inter-rater reliability. In a study of 56 in-patient subjects the agreement between three clinicians for the SCID was 85.7\% (kappa = 0.8189). Zimmerman, Sheeran and Young (2004:89), on the other hand, found an inter-rater reliability of 0.91 (kappa) for major depression. Huprich, Zimmerman and Chelminski (2006:392) report reliability figures of $\mathrm{k}=$ 0.98 for anti-social and $k=0.96$ for borderline personality disorder.

In terms of the SCID's ability to validly predict depression, a correlation of 0.83 with the Beck Depression Inventory (version II) was found by Sprinkle, Lurie, Insko, Atkinson, Jones, Logan and Bissada (2002:381). Schmitz, Kruse, Heckrath, Alberti and Tress (1999:364$5)$, on the other hand, found that the SCID has sufficient concurrent validity for the diagnosis of anxiety disorders when compared to the Symptom Checklist-90$R$ (area under ROC curve $=0.86$ ).

A point-biserial correlation of 0.73 was furthermore found between the SCID and Shedler-Westen Assessment Procedure-200 (SWAP-200) for the anti-social personality disorder (Marin-Avellan, Mcgauley, Campbell \& Fonagy, 2005:36). The same authors also report that a correlation of 0.45 was found between the SCID diagnosis of borderline personality disorder and the coercive-subscale of the CIRCLE Inventory (Marin-Avellan et al. 2005:38). Concurrent validity figures show a correlation of 0.52 between the SCID diagnosis of borderline personality disorder and scores on the Inventory of Interpersonal Problems (IIP-32) (Dent-Brown \& Wang, 2004:327).

\section{Hypotheses}

The following hypotheses were generated for univariate data:

\section{Null hypotheses A to E}

The categorical proportions of the dependent variables A to $E$ will not differ significantly between the treatment adherent and the treatment non-adherent groups.

\section{Research hypotheses A to E}

The categorical proportions of the dependent variables A to $\mathrm{E}$ will differ significantly between the treatment adherent and the treatment non-adherent groups.

\section{Statistical analysis of data}

\section{Univariate data}

For hypotheses A to E the Fisher's exact test was used 
in all cases where three or more dependent variable categories were present. The Fisher's exact test is a nonparametric test of significance for mutually exclusive categories and is particularly useful when sample groups are relatively small and expected frequencies in each of the cells are low (Howitt \& Cramer, 2005: 606).

\section{Significance level}

To avoid capitalising on chance and thereby avoiding a Type 1 error the customary significance level of 0.05 was divided by the number of dependent variables used in the study. An alpha level of $p=0.01(0.05 / 5)$ was therefore decided on.

\section{Multivariate data}

A logistic regression analysis was conducted to test the multiple predictive effects of statistically significant predictor variables on the criterion variable (treatment non-adherence). An alpha level of $p=0.01$ was chosen.

The SPSS version 9 was employed to analyse the data.

\section{Ethical considerations}

Upon admission clients are made aware that all information can be used for future research in the field of substance abuse treatment. Informed consent was also obtained from each client. Client variables were also recorded anonymously using the file number coding.

Informed permission was also obtained from the SHARP Treatment Centre to use the patient files for research purposes and clearance was obtained from the Research and Ethics Committee of the Psychology Department of the University of Johannesburg.

\section{RESULTS}

\section{Results concerning univariate data}

\section{Hypotheses A to E}

Table 2 shows that significant proportional differences were found for dependent variables $A$ and $C$. For the other variables there were no significant proportional differences between the adherent and the non-adherent groups. The null hypothesis is accepted in all cases except for legal history (dependent variable A) and medication on admission (dependent variable $\mathrm{C}$ ).

\section{Hypothesis A: Legal history}

The null hypothesis $A$ was rejected at the $p=0.01$ (Fisher's exact test $=12.369$ ). Table 3 shows that a significant difference was observed in terms of legal history between the two sample groups. Adherent patients seem to have a higher than expected criminal record (63.41\% compared to the expected $48.29 \%$ ).

Table 2: Results concerning hypotheses A-E

\begin{tabular}{|l|l|l|}
\hline Dependent variable & Fisher's exact test & 2-sided significance \\
\hline $\begin{array}{l}\text { A: Legal history } \\
\text { (Criminal record) }\end{array}$ & Fisher's exact $=12.369$ & $\mathbf{0 . 0 0 2}^{*}$ \\
\hline $\begin{array}{l}\text { B: Supplementary } \\
\text { medication current }\end{array}$ & Fisher's exact $=0.429$ & 0.883 \\
\hline $\begin{array}{l}\text { C: Supplementary } \\
\text { medication on } \\
\text { admission }\end{array}$ & Fisher's exact $=29.131$ & $\mathbf{0 . 0 0 0 ^ { * }}$ \\
\hline $\begin{array}{l}\text { D: Co-morbidity with } \\
\text { Axis I } \\
\text { psychopathology }\end{array}$ & Fisher's exact $=10.64$ & 0.042 \\
\hline $\begin{array}{l}\text { E: Co-morbidity Axis } \\
\text { II personality } \\
\text { disorders }\end{array}$ & Fisher's exact $=3.525$ & 0.180 \\
\hline
\end{tabular}


Table 3: Treatment adherence with legal history (Variable A)

\begin{tabular}{|c|c|c|c|c|}
\hline \multirow[t]{2}{*}{ Adherence } & & & & \\
\hline & $\begin{array}{l}\text { No criminal } \\
\text { record }\end{array}$ & Criminal record & $\begin{array}{l}\text { Arrest, but no } \\
\text { criminal record }\end{array}$ & Total \\
\hline $\begin{array}{l}\text { Adherent count } \\
\text { and } \%\end{array}$ & $\begin{array}{l}15 \\
38.58 \%\end{array}$ & $\begin{array}{l}26 \\
63.41 \%\end{array}$ & $\begin{array}{l}0 \\
0 \%\end{array}$ & 41 \\
\hline $\begin{array}{l}\text { Adherent } \\
\text { expected count } \\
\text { and } \%\end{array}$ & $\begin{array}{l}17.4 \\
42.44 \%\end{array}$ & $\begin{array}{l}19.8 \\
48.29 \%\end{array}$ & $\begin{array}{l}3.9 \\
9.51 \%\end{array}$ & \\
\hline $\begin{array}{l}\text { Non-adherent } \\
\text { count and } \%\end{array}$ & $\begin{array}{l}21 \\
51.21 \%\end{array}$ & $\begin{array}{l}15 \\
39.09 \%\end{array}$ & $\begin{array}{l}8 \\
18.18 \%\end{array}$ & 44 \\
\hline $\begin{array}{l}\text { Non-adherent } \\
\text { expected count } \\
\text { and } \%\end{array}$ & $\begin{array}{l}18.6 \\
42.27 \%\end{array}$ & $\begin{array}{l}21.2 \\
48.18 \%\end{array}$ & $\begin{array}{l}4.1 \\
9.31 \%\end{array}$ & \\
\hline Total & 36 & 41 & 8 & 85 \\
\hline
\end{tabular}

Table 4: Treatment adherence with medication used on intake (Variable C)

\begin{tabular}{|c|c|c|c|c|}
\hline \multirow[t]{2}{*}{ Treatment adherence } & \multicolumn{3}{|c|}{ Medication used on intake } & \multirow[b]{2}{*}{ Total } \\
\hline & $\begin{array}{l}\text { Psychiatric } \\
\text { drugs }\end{array}$ & $\begin{array}{l}\text { Psychiatric drugs and general } \\
\text { prescription medication }\end{array}$ & None & \\
\hline Adherent count and \% & $\begin{array}{l}18 \\
43.9 \%\end{array}$ & $\begin{array}{l}3 \\
7.32 \%\end{array}$ & $\begin{array}{l}20 \\
48.78 \%\end{array}$ & 41 \\
\hline $\begin{array}{l}\text { Adherent expected count } \\
\text { and } \%\end{array}$ & $\begin{array}{l}12.1 \\
29.51 \%\end{array}$ & $\begin{array}{l}14.5 \\
35.37 \%\end{array}$ & $\begin{array}{l}14.5 \\
35.37 \%\end{array}$ & 41 \\
\hline $\begin{array}{l}\text { Non-adherent count } \\
\text { and } \%\end{array}$ & $\begin{array}{l}7 \\
15.91 \%\end{array}$ & $\begin{array}{l}27 \\
61.36 \%\end{array}$ & $\begin{array}{l}10 \\
22.72 \%\end{array}$ & 44 \\
\hline $\begin{array}{l}\text { Non-adherent - expected } \\
\text { count and \% }\end{array}$ & $\begin{array}{l}12.9 \\
29.32 \%\end{array}$ & $\begin{array}{l}15.5 \\
35.29 \%\end{array}$ & $\begin{array}{l}15.5 \\
35.23 \%\end{array}$ & 44 \\
\hline Total & 25 & 30 & 30 & 85 \\
\hline
\end{tabular}

Table 5: Physical health, prescription medication on admission and medication given during treatment

\begin{tabular}{|l|l|l|l|l|l|l|l|l|}
\hline Adherence & \multicolumn{2}{l|}{ Physical health } & \multicolumn{2}{l|}{$\begin{array}{l}\text { Prescription medication } \\
\text { on admission }\end{array}$} & \multicolumn{2}{l|}{$\begin{array}{l}\text { Prescription medication } \\
\text { during treatment }\end{array}$} \\
\hline & Good & Chronic illness & Psychiatric & Mixed & None & Psychiatric & Mixed & None \\
\hline $\begin{array}{l}\text { n = } \\
\text { Adherent }\end{array}$ & 36 & 5 & 18 & 3 & 20 & 21 & 9 & 11 \\
\hline $\begin{array}{l}\mathbf{n}=\text { Non- } \\
\text { adherent }\end{array}$ & 41 & 3 & 7 & 27 & 10 & 22 & 12 & 10 \\
\hline
\end{tabular}


The treatment non-adherent group, on the other hand show larger-than-expected incidence for the categories of no criminal record ( $51.2 \%$, compared to the expected $42.27 \%$ ) and arrest, but no record (18.18\%, compared to the expected $9.31 \%)$. This could indicate a trend that the presence of a criminal record $(63.41 \%$ in the adherent group, as opposed to $34.09 \%$ in the non-adherent group) might serve as a motivation to complete treatment. Fearing further legal problems or even imprisonment might encourage patients to remain in treatment. Conversely, it seems that having no criminal record does not motivate a patient to adhere to treatment.

\section{Hypothesis C: Medication on admission}

The null hypothesis $C$ was rejected at the $p=0.01$ level (Fisher's exact test $=29.131$ ). Table 4 indicates that the non-adherent group has a larger-than-expected incidence of using a combination of general- and psychiatric prescription medication (61.36\%, as opposed to the expected $35.29 \%$ ). The non-adherent group also shows a lower-than-expected incidence of abstinence from medication ( $22.72 \%$, as opposed to the expected $35.23 \%)$.

This could indicate that the non-compliant group tended to overuse medication. This is confirmed if one takes into account that the vast majority $(41 / 44=93.2 \%)$ of treatment non-compliant participants were found to be physically healthy on admission to the rehabilitation programme (see Table 5). It would, therefore, seem that treatment non-compliant patients not only have a tendency to abuse substances, but also to abuse prescription medication in general. This is further confirmed by the fact that during treatment the number of noncompliant members receiving a combination or both psycho-active and general medical prescription drugs was reduced by $15(27-12=15)$ after admission to the treatment programme (see Table 5). This would indicate that these patients were using an unnecessary amount of general prescription drugs before treatment. Also, bearing in mind that no non-adherent patients were diagnosed with anxiety-based disorders (see Table 6), one can then confidently rule out that any of them suffered from somatoform disorders. (Somatoform disordered persons falsely believe that they have physical symptoms and therefore tend to unnecessarily resort to medication.) It, therefore, seems clear that noncompliant patients tend to abuse prescription medication in general.

Table 4 furthermore indicates that the treatment-adherent group had a higher-than-expected incidence of taking psychiatric medication $(43.9 \%$, as opposed to the expected $29.51 \%$ ). The compliant group, however, did not have a history of overmedication by taking a combination of general medicine with psychiatric drugs. Given the relatively high incidence of Axis I pathology $(30 / 41=73.17 \%)$ in this group, one would assume that the medication taken by this group was appropriate to their psychiatric problems (see Table 6).

It is therefore evident that non-compliant patients show a tendency to overuse a combination of general and psychiatric medication, whereas compliant patients take psychiatric medication when appropriate to alleviate Axis I symptoms. It is also interesting to note that patients receiving prescribed psychiatric medication in the treatment-compliant group increased during treatment $(21 / 41=51.22 \%$, as opposed to $18 / 41=43.9 \%$ prior to the rehabilitation programme), which indicates that the psychiatrists deemed it necessary to treat the Axis I pathology with psychiatric drugs (see Table 5). This further confirms the notion that the medication in this group was appropriate.

\section{Multivariate data}

A logistic regression analysis was conducted to assess the relative effects of the significant predictors of

Table 6: Treatment adherence with Axis I co-morbidity

\begin{tabular}{|c|c|c|c|c|c|c|c|}
\hline \multirow[b]{2}{*}{ Adherence } & \multicolumn{6}{|c|}{ Axis I Co-morbidity } & \multirow[b]{2}{*}{ Total } \\
\hline & $\begin{array}{l}\text { Anxiety } \\
\text { based }\end{array}$ & $\begin{array}{l}\text { Mood } \\
\text { disorder }\end{array}$ & Psychosis & $\begin{array}{l}\text { Eating } \\
\text { disorder }\end{array}$ & ADHD & None & \\
\hline Adherent & 7 & 16 & 1 & 3 & 3 & 11 & 41 \\
\hline Non-adherent & 0 & 18 & 1 & 8 & 2 & 15 & 44 \\
\hline
\end{tabular}


Table 7: Variables in the equation predicting treatment non-adherence

\begin{tabular}{|l|l|l|l|l|l|l|l|}
\hline $\begin{array}{l}\text { Dependent } \\
\text { variables and } \\
\text { their categories }\end{array}$ & $\boldsymbol{\beta}$ & $\begin{array}{l}\text { Standard } \\
\text { error }\end{array}$ & $\begin{array}{l}\text { Wald } \\
\text { statistic }\end{array}$ & $\begin{array}{l}\text { Degrees } \\
\text { of } \\
\text { freedom }\end{array}$ & $\begin{array}{l}\text { Significance } \\
\text { level }\end{array}$ & $\begin{array}{l}\mathbf{R} \\
\text { (Correlation) }\end{array}$ & Exp ( $\boldsymbol{\beta})$ \\
\hline Past medication & & & 14.7819 & 2 & $0.0006^{*}$ & 0.3026 & \\
\hline $\begin{array}{l}\text { Psychiatric } \\
\text { medication }\end{array}$ & -.4201 & 0.6143 & 0.4676 & 1 & 0.4941 & 0.0000 & 0.6570 \\
\hline $\begin{array}{l}\text { Mixed psychiatric } \\
\text { \& general } \\
\text { prescription } \\
\text { medication }\end{array}$ & 2.4842 & 0.7455 & 11.1035 & 1 & $0.0009^{*}$ & 0.2781 & 11.9921 \\
\hline Legal history & & & 3.2016 & 2 & 0.2017 & 0.0000 & \\
\hline No criminal record & -5.827 & 21.3778 & 0.0743 & 1 & 0.7852 & 0.0000 & 0.0029 \\
\hline Criminal record & -6.803 & 21.3759 & 0.1013 & 1 & 0.7503 & 0.0000 & 0.0011 \\
\hline Constant & 5.7182 & 21.3786 & 0.0715 & 1 & 0.7891 & & \\
\hline
\end{tabular}

Table 8: Predicted probabilities of non-adherence calculated for categories of past medication and a combination of past medication and legal history

\begin{tabular}{|l|l|}
\hline Predictor categories & Predicted probabilities of non-adherence \\
\hline $\begin{array}{l}\text { Mixed psychiatric medication and general } \\
\text { prescription medication }\end{array}$ & 0.9 \\
\hline $\begin{array}{l}\text { Mixed psychiatric medication and general } \\
\text { prescription medication with no legal history }\end{array}$ & 0.91493 \\
\hline $\begin{array}{l}\text { Mixed psychiatric medication and general } \\
\text { prescription medication with arrest, but no } \\
\text { criminal record }\end{array}$ & 0.99973 \\
\hline
\end{tabular}

legal history and medication on admittance on the encoded criterion variable sub-category of treatment nonadherence. All 85 cases were taken into account in the analysis and the full model was significantly reliable $\left(\dot{\div}^{2}=35.581, \mathrm{df}=4, \mathrm{p}=0.000\right)$. The model furthermore explains between $34.2 \%$ (Cox \& Snell $=0.342$ ) and $45.6 \%$ (Nagelkerke $=0.456$ ) of the variance. The model also predicts $92.68 \%$ of adherent and $61.36 \%$ of nonadherent patients accurately. The full model therefore predicts $76.47 \%$ of the overall cases successfully.

Table 7 indicates that the category of a combination of psychiatric and general prescription drugs serves as the only reliable single predictor for treatment non-adherence $($ Wald statistic $=11.1035, p=0.0009)$. None of the other categories of this variable served as an accurate single predictor of non-compliance at the $p=$ 0.01 level. Using a combination of psychiatric and general prescription medication (as opposed to using no medication) increases the odds of being non-compliant by a factor of 2.4842 (estimated coefficient â). Table 7 also shows that legal history fails to explain any further variance that past medication cannot explain on its own.

When predicted probabilities of non-adherence are, however, calculated for the categories of past medication and past medication in conjunction with legal history, the following results are obtained (see Table 8). 
Table 8 indicates that the predicted probability of being non-adherent, if a combination of psychiatric and general prescription drugs is abused, was 0.9 or $90 \%$.

Although variables of legal history and Axis I pathology do not have single significant predictor qualities, they do interact with medication on admission to enhance the predicted probabilities of certain categories. In this regard it has to be noted that the probability of nonadherence increases when certain combinations of variable categories are found. The probability of being noncompliant to treatment increases from $90 \%$ to $91.49 \%$ if the patient lacks a criminal record but shows a tendency to abuse both psychiatric and general prescription medication. Lacking a criminal record with the abuse of a mixture of psychiatric and general prescription medication furthermore increases the probability of non-compliance to $99.97 \%$.

In conclusion, it is therefore evident that although the general abuse of psychiatric- and other medication serves as an accurate predictor of non-compliance, its predictive effects are enhanced by some categories of legal history.

\section{DISCUSSION}

\section{Dependent variables not affecting treat- ment adherence or non-adherence}

\section{Supplementary medication current}

No significant differences were noted in the sample groups in terms of medication received during the treatment phase. This indicates that once patients were accepted into the treatment programme, additional medication was properly monitored by the physician and psychiatrist. Patients therefore only received necessary and appropriate medication and were not overmedicated.

It is furthermore interesting to note that the treatment adherent group's psychiatric medication was increased, whereas the treatment non-adherent group received less psychiatric and general medication after admission to the treatment programme. This confirms the notion that the treatment non-adherent group tended to use medication unnecessarily before admission. This observation is important as it impacts on the later discussion of the predictive value of the abuse of medication on treatment compliance.

\section{Co-morbidity with Axis I psychopathology}

Findings indicate that Axis I pathology does not accurately predict treatment adherence. This finding is in line with the findings of Brown et al. (2001:154) and Agosti et al. (1996:29) reported in the literature section. This finding should, however be interpreted with caution as the sample was relatively small and subcategories of the variable were even smaller. There are indications, albeit statistically insignificant, that anxiety-based disorders could relate to compliance in treatment. In this regard future research should aim at obtaining a larger sample in order to clarify this matter.

\section{Co-morbidity Axis II - Cluster B}

Although a high incidence of borderline $(20 / 85=23.52 \%)$ and anti-social $(20 / 85=23.52 \%)$ pathology was found in both sample groups, the proportions did not differ significantly. The high incidence of Cluster B personality disorder in addicts confirms the findings of Ball et al. (2005:371).

The finding that neither borderline nor anti-social personality disorder accurately predicts premature treatment drop-out confirms the research of Ravndal et al. (2005:183).

\section{Reliable predictors of treatment non-ad- herence}

The results indicate that the single most reliable predictor of non-compliance is a tendency to over-use a mixture of psychiatric and general prescription medication. This is a novel finding that has not been researched before and does not appear in the reviewed literature on treatment non-adherence. The finding does however confirm psychodynamic factors cited in the causation and maintenance of serious substance addiction. In this regard Sadock and Sadock (2003:386) state that individuals prone to substance related disorders not only tend to regress to the oral level, but also have the tendency to self-medicate. Oral regression refers to a tendency to return to an early stage of dependency where the mouth is the focus of drive reduction. Addicts seem to have a propensity to deal with difficulties by means of oral gratification (drinking or taking tablets) as a form of problem-solving or self-soothing. This pattern might additionally have been reinforced 
by parents who tended to give the child medication (for example, a pain pill or a tranquilliser) as a quick solution, instead of teaching the child skills to resolve the difficulty. This could result in an ingrained tendency to seek instant oral solutions to problems instead of dealing with the difficulty or conflict in a more laborious, but constructive way. Apart from this, 'quick solutions' also reinforce impulsive acting-out inclinations in a child. A person, therefore, with both oral gratification and impulsive tendencies will not be committed to the painful and time-consuming process of rehabilitation, and would more readily abandon the treatment programme.

Having developed an affinity to abuse permissible psychiatric and general medication might lower a person's inhibitions to abuse illicit substances. Such a person would also find it easier to rationalise and to deny the addiction, as it was originally based on a 'legitimate solution' to a problem. In this regard, obtaining a script for a medical or psychiatric drug from a doctor or psychiatrist serves as a legitimising reason to obtain a quick solution or instant gratification. Clients with such defensive patterns of rationalisation and denial will, therefore, more readily drop out of treatment, because they cannot commit themselves to complete abstinence from oral gratification tendencies.

Results furthermore show that the double combination of medication on admittance and legal history increase the predicted probability of non-adherence. In this regard results show that a combination of using both psychiatric and general prescription medication with either no criminal record or a history of arrest but no conviction increases the chance of non-compliance. Having been arrested but not convicted could furthermore strengthen the belief that a person will be able to escape the adverse consequences of his or her actions. The intervention from parents and lawyers may furthermore strengthen the belief that others will rescue the individual and that one need not take responsibility for actions. Not being concerned with the adverse consequences of one's behaviour would then negatively impact on the client's commitment to comply with treatment.

\section{Practical implications of the findings}

From the previous section it seems that treatment dropouts seem to abuse medication in general, want a quick solution, and are not concerned about the consequences of their actions. Early identification of such clients could alert addiction counsellors and psychiatric consultants to adapt their rehabilitation programmes to deal with the special difficulties that such persons present. In this regard additional treatment such as Dialectical Behavioural Therapy (DBT) may help to curb impulsiveness, low frustration tolerance and poor adaptive skills. In this regard additional DBT could serve the following therapeutic functions: "(1) to enhance and expand the patient's repertoire of skilful behaviour patterns; (2) to improve patient motivation to change by reducing reinforcement of maladaptive behaviour, including dysfunctional cognition and emotion; (3) to ensure that new behavioural patterns generalize from the therapeutic to the natural environment; (4) to structure the environment so that effective behaviours, rather than dysfunctional behaviours, are reinforced; and (5) to enhance the motivation and capacities of the therapist so that effective treatment is rendered" (Sadock et al. 2003:955).

\section{EVALUATION OF THE STUDY}

\section{Positive contributions}

The study provided new information with regard to the possibility that a history of unnecessary use of prescription medication prior to treatment may contribute negatively to treatment adherence. This aspect of treatment compliance has never before been investigated and the current study therefore makes a significant new contribution to the existing body of knowledge. The fact that a past history of no criminal record has an additive effect in addition to the aforementioned factor furthermore adds novel information.

It appears that no such study has previously been conducted in South Africa. This study therefore contributes to the limited research on substance abuse treatment in South Africa.

\section{Limitations}

Although the information gained from the study is significant, the study needs to be assessed within the context of its limitations. In the first place the size of the sample studied was relatively small $(n=85)$ and may not provide an accurate description of the general 
population of addicts needing drug rehabilitation. The sample consisted mainly of veteran substance abusers who were white from middle-class socio-economic backgrounds and receiving institutionalised treatment. It is not likely that this represents South Africa's entire population of addicts eligible for rehabilitation.

The relatively small sample was mostly due to the limitations of archival research. Archival research presents its own restrictions in that only the available data can be scrutinised. Data from some files were incomplete and could, therefore, not be used for the purpose of the study. Archival information is also limited as follow-up questions cannot be asked. This prevents deeper and more nuanced scrutiny of the material.

Axis I categories in the study are possibly too broad to determine the influence of specific disorders. Mood disorders may well contribute towards non-adherence of treatment, but more specific categories might be required to determine their role in non-compliance. In this regard future research might distinguish between categories of bipolar and unipolar disorders. This would also apply to the spectrum of eating disorders and anxiety-based disorders.

The results lastly suggest that a history of general pharmaceutical abuse may predispose an individual towards non-adherence, but it is not clear which specific medications or classes of drugs are involved.

\section{SUGGESTIONS FOR FURTHER RE- SEARCH}

Future research could focus on a more detailed profile of medication use influencing the patterns of treatment adherence. For example, what specific psychiatric and other medications play a role in premature drop-out?

To clarify the role of Axis I pathology in treatment adherence, in future a far larger sample of addicts with co-morbidity of anxiety and mood disorders should be employed.

Prospective studies also need to employ a larger and more representative sample in the South African context. Such studies could also employ treatment modalities that are specifically suited to the cultural and religious needs of the South African population.
Qualitative research concerning characteristics of clients who prematurely drop out of treatment could add further depth to our understanding of this phenomenon.

\section{CONCLUSION}

Non-compliance in rehabilitation programmes remains a significant problem which has serious prognostic implications. Identifying reasons for non-adherence could enable care-givers to refine treatment plans in such a way that pre-mature drop-out is largely curtailed.

\section{REFERENCES}

AGOSTI, V; NUNES, E \& OCEPECK-WELIKSON, K 1996: Patient factors related to early attrition from an outpatient cocaine research clinic. American Journal of Drug and Alcohol Abuse, 22(1):29-39.

BALL, SA; COBB-RICHARDSON, P; CONNOLLY, AJ; BUJOSA, CT \& O'NEALL, TO 2005: Substance abuse and personality disorders in homeless drop-in center clients: Symptom severity and psychotherapy retention in a randomized clinical trial. Comprehensive Psychiatry, 46:371-379.

BROWN, BS; O'GRADY, KE; FARRELL, EV; FLECHNER, IS \& NURCO, DN 2001: Factors associated with frequency of 12-step attendance by drug abuse clients. American Journal of Drug and Alcohol Abuse, 27(1):147-160.

CLAUS, RE \& KINDLEBERGER, LR 2002: Engaging substance abusers after centralized assessment: Predictors of treatment entry and drop-out. Journal of Psychoactive Drugs, 34(1):25-30.

COPELAND, J \& HALL, W 1992: A comparison of predictors of treatment drop-out of women seeking drug and alcohol treatment in a specialist women's and two traditional mixed-sex treatment services. British Journal of Addiction, 87:883-890.

DENT-BROWN, K \& WANG, M 2004: Developing a rating scale for projected stories. Psychology and Psychotherapy: Theory, Research and Practice, 77:325-333.

GILLMORE, JD; LASH, SJ; FOSTER, MA \& BLOSSER, SL 2001 Adherence to substance abuse treatment: Clinical utility of two MMPI-2 scales. Journal of Personality Assessment, 77(3):524-540.

HALLER, DL; MILES, DR \& DAWSON, KS 2002: Psychopathology influences treatment retention among drug-dependent women. Journal of Substance Abuse Treatment, 23:431-436. HOSKIN, G 2007: Alcohol, drug crisis grips South Africa. Pretoria News, August 21:1.

HOWITT, D \& CRAMER, D 2005: Introduction to Statistics in Psychology; $3^{\text {rd }}$ edition. New York: Prentice Hall.

HUPRICH, SK; ZIMMERMAN, MA \& CHELMINSKI, I 2006: Should 
self-defeating personality disorders be revisited in the DSM? Journal of Personality Disorders, 20(4):388-400.

KELLY, JF \& MOOS, R 2003: Drop-out from 12-step self-help groups: Prevalence, predictors, and counteracting treatment influences. Journal of Substance Abuse Treatment, 24(3):341250.

KING, AC \& CANADA, SA 2004: Client-related predictors of early treatment drop-out in a substance abuse clinic exclusively employing individual therapy. Journal of Substance Abuse Treatment, 26:189-195.

MARIN-AVELLAN, LE; MCGAULEY, C; CAMPBELLL, C \& FONAGY, $P$ 2005: Using the SWAP-200 in a personality-disordered forensic population: Is it valid, reliable and useful? Criminal Behaviour and Mental Health, 15:28-45.

MILLER, PR; DASHER, R; COLLINS, R; GRIFFITHS, P \& BROWN, F 2001: Inpatient diagnostic assessments: 1. Accuracy of structured vs. unstructured interviews. Psychiatry Research, 105:255-264.

NELSON-GRAY, RO; HUPRICH, SK; KISSLING, GE \& KETCHUM, K 2004: A preliminary examination of Beck's cognitive theory of personality disorders in undergraduate analogues. Personality and Individual Differences, 36:221-233.

RAVNDAL, E; VAGLUM, P \& LAURITZEN, G 2005: Completion of long-term inpatient treatment of drug abusers: A prospective study from 13 different units. European Addiction Research, 11:180185.

SADOCK, BJ \& SADOCK, VA 2003: Kaplan and Sadock's Synopsis of Psychiatry; $9^{\text {th }}$ edition. Philadelphia: Lippincott Williams \& Wilkins.

SANNIBALE, C; HURKETT, P; VAN DEN BOSSCHE, D; O'CONNOR, D; ZADOR, C; CAPUS, K; GREGORY, K \& MCKENZIE, M 2003: Aftercare attendance and post-treatment functioning of severely substance dependent residential treatment clients. Drug and Alcohol Review, 22(June):181-190.

SCHMITZ, N; KRUSE, J; HECKRATH, C; ALBERTI, L \& TRESS, W 1999: Diagnosing mental disorders in primary care: The General Health Questionnaire (GHO) and the Symptom Check List (SCL90-R) as screening instruments. Society or Psychiatry and Psychiatric Epidemiology, 34:360-366.

SLESNICK, N 2001: Variables associated with therapy attendance in runaway substance abusing youth: Preliminary findings.

American Journal of Family Therapy, 29:411-420.

SPRINKLE, SD; LURIE, D; INSKO, SL; ATKINSON, G; JONES, GL; LOGAN, AR \& BISSADA, NN 2002: Criterion validity, Severity cut scores and test-retest reliability of the Beck depression inventory-II in a university counselling centre sample. Journal of Counselling Psychology, 49(3):381-385.

VENDETTI, J; MCREE, B; MILLER, M; CHRISTIANSEN, K\& HERRELL, $\mathrm{J}$ 2002: Correlates of pre-treatment drop-out among persons with marijuana dependence. Addiction, 97:125-134.

WICKIZER, T; MAYNARD, C; ATHERLY, MA; FREDERICK, M; KOEPSELL, T; KRUPSKI, A\& STARK, K 1994: Completion rates of clients discharged from drug and alcohol treatment programs in Washington State. American Journal of Public Health, 84(2):215-221.

ZIMMERMAN, M; SHEERAN, T \& YOUNG, D 2004: The diagnostic inventory for depression: A self-report scale to diagnose DSM-IV major depressive disorder. Journal of Clinical Psychology, 60(1):87-110. 